\title{
Peran Instagram @greenarationid sebagai Media Kampanye Ramah Lingkungan
}

\author{
Iqbal Yusra Karim*, Neni Yulianita
}

Prodi Public Relation, Fakultas Ilmu Komunikasi, Universitas Islam Bandung, Indonesia.

*iqbalyusrakarim@gmail.com, yulianita.neni@gmail.com

\begin{abstract}
Social media facilitates users to do activities or collaborate so that they connect with other users. This research The role of Instagram @greenerationid as an Environmentally Friendly Campaign Media aims to show the role of social media in campaigns that apply the management function or the role of PR in managing communication, which cannot separate from interactions with the public, both with internal publics and external publics of the company to get a good image and reputation. This research uses a case study approach and approach, examines and analyzes the communication and strategy of the media team in managing the @ greenerationid Instagram account as an environmentally friendly media campaign. This research on the role of Instagram as an environmentally friendly campaign media shows that the programs created by GF campaigning for SCP issues communicate through Instagram. Have a series of planned communications to a broader audience and Cooperation partners to build a positive image. In the process, there are PR activities and PR in Instagram management through social media functions.
\end{abstract}

Keywords: Sustainable Consumption and Production, Social Media, Campaign, Greeneration Foundation

Abstrak. Media sosial memfasilitasi pengguna untuk beraktivitas atau berkolabolarasi sehingga terhubung dengan pengguna lainnya. Dalam penelitian ini Peran Instagram @ greenerationid sebagai Media Kampanye Ramah Lingkungan bertujuan memperlihatkan peran media sosial dalam kampanye yang mengaplikasikan fungsi manjemen atau peranan PR dalam pengelolaan komunikasi, dimana tidak terlepas dengan adanya interaksi dengan publik- publik, baik itu dengan publik internal maupun publik eksternal perusahaan sehingga mendapatkat citra dan reputasi yang baik. Penelitian ini menggunakan metode kualitatif dan pendekatan studi kasus, mengkaji dan menganalisis komunikasi dan strategi tim media dalam mengelola akun Instagram @ greenerationid sebagai media kampanye ramah lingkungan. Penelitian mengenai Peran Instagram sebagai media kampanye ramah lingkungan ini memperlihatkan Program-Program yang diciptakan GF mengkampanyekan isu SCP dikomunikasikan melalui Instagram. Memiliki serangkaian komunikasi yang terencana kepada khalayak luas dan juga mitra kerjasama untuk menciptakan citra positif. Dalam prosesnya terdapat aktifitas dan PR dalam pengelolaan Instagram melalui fungsi media sosial.

Kata Kunci: Sustainable Consumption and Production, media sosial, kampanye, Greeneration Foundation. 


\section{A. Pendahuluan}

Makhluk sosial khususnya manusia membutuhkan aktivitas konsumsi dan produksi, baik barang habis pakai atau menjadi sampah. Keterkaitan segala aktivitas manusia dan permasalahan pada lingkungan hidup sebenarnya tidak sederhana, masalah sampah contohnya, masalah klasik yang terus hangat untuk diperbincangkan, ini memperlihatkan bukan hanya pada boleh atau tidak bolehnya susuatu aktivitas dilakukan oleh manusia. Namun, jauh dari itu diharapkan manusia atau perseorangannya dapat bertanggungjawab apa saja yang merusak lingkungan pada akhirnya.

Dalam kehidupan sehari-hari, manusia atau individunya dihadapkan dalam pelbagai pilihan untuk berperilaku, baik itu yang merusak lingkungan atau pun sebaliknya, bermanfaat bagi lingkungan. Untuk dapat mendukung juga memdedahkan kepedulian penduduk terhadap lingkungan, maka perlu dilakukan atau diberikan diskurkur pemahaman akan pentingnya menjaga kelestarian lingkungan hidup.

Menjadi acuan agenda pembangunan nasional NAWACITA, diterjemahkan sebagai arah utama RPJMN 2015-2019 hingga RPJMN 2020-2024, ini bertujuan untuk meningkatkan kesejahteraan masyarakat. Sejatinya, tujuan ini selaras dengan Tujuan Pembangunan Berkelanjutan(TPB) atau yang akrab dikenal Sustainable Development Goals (SDGs) yang merupakan kesepakatan dari 193 negara anggota Perserikatan Bangsa-Bangsa yang ditetapkan pada tahun 2015 yaitu meningkatkan kesejahteraan masyarakat global, termasuk Indonesia.

Pelaksanaan ini juga di lakukan oleh Non Government Organization (NGO). Untuk capaian 17 ini dirasa perlu seluruh elemen untuk menggaungkannya, maka organisasi juga dapat berfokus pada satu indicator saja. Seperti Greeneration Foundation sebagai NGO di Indonesia juga berfokus untuk memastikan konsumsi dan produksi yang berkelanjutan atau SCP.

Definisi yang umum digunakan mengenai SCP yakni "penggunaan layanan dan produk terkait yang menanggapi kebutuhan dasar menghadirkan kualitas hidup yang lebih baik sekaligus meminimalkan penggunaan sumberdaya alam dan bahan beracun serta emisi limbah dan polutan slama siklus hidup layaanatau produk agar tidak mengganggu kebutuhan generasi mendatang "(ISSD 1994).

Kini, di era komunikasi yang kian berkembang, hadirlah media sosial, dimana media ini muncul untuk memudahkan interaksi sosial yang bersifat interaktif dengan dukungan jaringan internet, yang mana mengubah cara penyebaran informasi yang sebelumnya (satu arah ke banyak) kini berganti ke media sosial dua arah (mutual, banyak arah).

Demokratisasi informasi pun hadir dan mudahnya ilmu pengetahuan didapat memudahkan pengubahan perilaku pengguna, dari yang sebelunya mengonsumsi konten, kini memproduksi konten. Dengan media sosial, pelbagai aktifitas komunikasi yang interaktif dalam segala bentuknya, seperti kolaborasi antar pengguna, sebuah diskursus, bertukarnya informasi, visual atau pun audiovisual dapat dilakukan. "Dalam media sosial terdapat tiga hal; Sharing, Collaborating, Connecting(Puntoadi, 2011)."

Dewasa ini menjadikan media sosial sebagai sebuah set komunikasi dan alat kolaborasi baru, memungkinkan dimana terdapat banyak jenis interaksi yang mana sebelumnya tidak tersedia bagi orang biasa.(Brogan, 2010).

Menurut Napitulu, New media merupakan digitalisasi yang mana sebuah konsep pemahaman mengikuti perkembangan zaman menyangkut teknologi dan sains, dari semula yang bersifat manual menjadi otomatis, dan dari semua yang bersifat rumit menjadi ringkas. (Djap, 2013:27).

Dapat dilihat bahwa new media ini memang berkembang seiring nya zaman agar semua orang bisa menjangkau kegiatan sehari-hari nya agar lebih fleksibel. Dalam penelitian ini terlekak pada titik peran suatu media sosial Instagram yang mana media sosial tersebut berkaitan dengan adanya new media.

Menurut Dijk (2003) dalam (Nasrulla 2016:11) Media sosial adalah platform media yang memfokuskan pada eksistensi pengguna yang memfasilitasi mereka dalam beraktifitas maupun berkolaburasi, Karena itu media sosial dapat dilihat sebagai medium( fasilitator) online yang menguatkan hubungan antar pengguna sekaligus sebagai sebuah ikatan sosial. 
Instagram menjadi salah satu platform yang menunjang komunikasi dua arah bagi masing-masing penggunanya. Melalui Likes, Comment, Share, saved, direct message, juga Hashtag. Masih ingat aktivitas termuda Greta Tintin Eleonora Ernman Thunberg, yang menggagas gerakan friday for future diorganisir oleh sekelompok anak muda School Climate Strike. Yang muncul di explore nstagram juga sehinga diketahui oleh masyarakat dunia.

Peneliti melihat adanya juga penggunaan kampanye di Indonesia melalu Instagram. Kampanye pada prinsipnya merupakan suatu proses kegiatan komunikasi individu atau kelompok yang dilakukan secara terlembaga dan bertujuan untuk menciptakan suatu efek atau dampak tertentu. Rogers dan Storey, 1987 mendefiniskan "Serangkaian tindakan komunikasi yang terencana dengan tujuan untuk menciptakan efek tertentu pada sejumlah besar khalayak yang dilakukan secara berkelanjutan pada kurun waktu tertentu," (Ruslan: 23, 2013).

Sama halnya dengan Greeneration Foundation (GF), yang mana mendorong masyarakat dan juga stakeholder untuk bisa membangun pola hidup konsumsi dan produksi yang berkelanjutan. GF banyak melakukan edukasi, kampanye dan advokasi kepada pemeritah. Kini, GF memiliki pengelolaan sampah di kawasan pariwisata, hal ini dikarenakan melihat pemerintah yang akan fokus terhadap pariwisata, jika insfrastuktur sampah tidak disiapkan dengan baik, maka GF yakin akan berbahaya bagi asset pariwisata itu sendiri. Program ini pun dinamakan Eco Ranger.

Pada level lainnya, GF pun menciptakan Indonesia Circular Economy Forum [ICEF] yang menjadi tempat berdiskusi High Level, seperti pemilik perusahaan/ organisasi, pemerintah mengenai apa saja tantangan Indonesia untuk mewujudkan Circular Economy. Kampanye lainnya juga yakni GF memiliki event setahun sekali yakni jamboree, Bersama 34 provinsi concenrt terhadap isu lingkungan di Indonesia.

Program-program Greeneration Foundation pun menjadikan organisasi non profit ini memiliki brand image yang baik soal lingkungan. Citra yang dibangun dari adanya NGO ini yang mengampanyekan SCP dapat diterima masyarakat dengan hadirnya sejak tahun 2005 dan banyaknya program yang terlaksana. Program dan kampanye pun dilakukan dengan offline dan online, selaras dengan citra di offline, pada platform online pun dengan masyarakat maya (khususnya Instagram) yang ada, GF memiliki citra yang baik. Menurut tools yang peneliti gunakan untuk menganalisa performa @ greenerationid, pada Kamis (14/07/2021) menunjukan:

1. Followers: 16,2 ribu

2. Engagement Rate: 0,59.

Pertumbuhan followers terus bertambah, Hal ini menunjukkan dimana GF mengelola media sosialnya (Instagram) dengan baik. Lalu, dalam kampanye ini ada satu fungsi yang dilakukan oleh GF yang peneliti amati, yaitu Public Relations.Public Relations merupakan jembatan antara pihak internal suatu perusahaan dengan pihak eksternal perusahaan, pihak eksternal perusahaan itu adalah stakeholders, masyarakat, media dan yang lainnya.

Pada umumnya kegiatan Public Relations adalah mengupayakan adanya goodwill yang terjadi pada publiknya, dan upaya ini sangat diperlukan dalam berbagai macam organisasi baik besar maupun kecil (dalam Yulianita, 2012:32). GF yang membawa isu SDG pastinya sangat memerlukan citra yang baik agar kampanyenya dapat terlaksana dengan baik.

Digital Public Relations ini sendiri sama hal nya dengan tujuan dari peran PR, untuk menjaga citra dari suatu perusahaan. Dalam buku (Nasrullah: 2016: 14) "Kegiatan PR yang dilakukan secara PR Digital tentu bersinergi dengan kegiatan PR yang dilakukan secara offline. Diantara kedua kegiatan ini tentu memiliki benang merah yang harus konsisten antara satu dengan yang lain.”

Dalam dunia ke PR-an terdapat empat tahap operasional PR yang dikemukakan oleh (Cutlip \& Center dalam Yulianita, 2012: 123) bahwa operasional Public Relations haruslah melalui 4 tahapan yaitu: 1) Defining Public Relations Problems, 2) Planning and Programming, 3) Communicating 4) Evaluation.

Paparan yang ada menjadi acuan untuk tujuan penelitian ini, menggambarkan bagaimana peran Instagram sebagai media kampanye ramah lingkungan bagi Greeneration Foundation dengan komunikasi untuk memberikan pemahahaman, pengetahuan, dan menanamkan rasa kepedulian masyarakat terhadap Sustainable Consumption and Production. 
Dapat terlihat secara kasat mata tanpa adanya pesan yang disublimasi, Greeneration, konten yang dihadirkan berupa kampanye terhadap lingkungan. Sehingga muncul pertanyaan 1)Mengapa Greeneration Foundation menggunakan Instagram sebagai media kampanye ramah lingkungan?2)Bagaimana peran Instagram mendukung program yang dilakukan Greeneration Foundation? 3)Bagaimana proses tim media dalam mengelola akun Instagram @ greenerationid sebagai media kampanye ramah lingkungan?

\section{B. Metodologi Penelitian}

Dalam penelitian ini, paradigma yang digunakan konstruktivisme. Menurut Guba (dalam Gunawan, 2015:49) Konstruktivisme yaitu pengetahuan dapat digambarkan sebagai hasil atau konsekuensi dari aktivitas manusia, pengetahuan merupakan konstruksi manusia, tidak pernah dipertanggungjawabkan sebagai kebenaran yang tetap tetapi merupakan permasalahan dan selalu berubah. Peneliti menggunakan teori kampanye dimana teori ini dapat masuk ke dalam paradigma konstruktivisme.

Penelitian menggunakan jenis penelitian kualitatif yang mana hasil temuannya induktif dan tidak diperoleh melalui prosedur perhitungan atau statstik, sehingga metodologi dalam penelitian kualitatif berfokuskan kepada kualitas dari objek akan yang diteliti dan pengungkapan makna serta pengalaman subjek penelitian terhadap fenomena yang ada, atau dengan kata lain dapat dikatakan penelitian kualitatif mendapatkan data sesuai dengan yang diperoleh secara real dari lapangan penelitian. .

Sehingga metodologi dalam penelitian kualitatif berfokuskan kepada kualitas dari objek akan yang diteliti dan pengungkapan makna serta pengalaman subjek penelitian terhadap fenomena yang ada, atau dengan kata lain dapat dikatakan penelitian kualitatif mendapatkan data sesuai dengan yang diperoleh secara real dari lapangan penelitian.

Menurut Creswell (2012) dalam (Sugiyono, 2017:5) Studi kasus menjadi salah satu genre penelitian kualitatis dimana proses atau ekplorasi pada suatu kejadian dan peneliti mengumpulkan data yang detail dengan waktu yang berkesinambungan. Pada pendekatan studi kasus yang memegang peranan utama nya adalah peneliti.

\section{Hasil Penelitian dan Pembahasan}

Hasil penelitian dan pembahasan yang diperoleh baik secara observasi, wawancara, serta studi kepustakaan. Temuan penelitian ini akan membahas tentang bagaimana Peran Instagram @ greenerationid sebagai media kampanye ramah lingkungan.

\section{Penggunaan Instagram Greeneration Foundation sebagai media kampanye ramah lingkungan}

Greeneration Foundation. dalam prakteknya berfokus pada kampanye SDG's no.12, isu SCP. Disajikan melalui program yang akhirnya menciptakan citra dan reputasi yang diinginkan sesuai visi dan misi nya. Memiliki program yang perlu di komunikasikan kepada masyarakat sehingga perlu adanya medium dan pengelolaan yang terelaborasi. karena.

Instagram digunakan GF dan dipilih sebagai media kampanye ramah lingkungan,

1. Media kreatif, memanfaatkan media sosial yang memiliki jangkauan yang luas

2. Target GF yang tersaring banyak berada di Instagram

3. Terpenuhinya Fungsi media sosial Sharing, Collaborating, Connecting (Puntoadi, 2011).

4. Networking dan komunikasi dengan mitra, partnership, masyarakat (audience)

GF sebagai Non Government Organisation memiliki program-program untuk mendukung kampanye, kampanye ini tentunya membutuhkan audience yang meluas untuk terjalankan. Sebuah NGO non profit seperti GF memiliki tujuan yang bersifat sosial. Seperti menurut Charles U Larson, bukunya berjudul persuasion, Reception and Responsibility (California. Wardsworth Publishing Co.1992) yang membagi jenis kampanye salah satunya yang dilakukan GF yakni Ideological or Cause -Oriented Campaigns, Jenis kampanye ini berorientasi yang bertujuan bersifat khusus dan berdimensi perubahan social (social cange campaigns). 
Kampanye GF dalam isu SDG's poin 12 mengenai suistanable production and consumtion diharapkan untuk audience lebih aware. Seperti yang di definiskan oleh Rogers dan Storey 1987"Serangkaian tindakan komunikasi yang terencana dengan tujuan untuk menciptakan efek tertentu pada sejumlah besar khalayak yang dilakukan secara berkelanjutan pada kurun waktu tertentu," (Ruslan: 23, 2013).

Mendapatkan khalayak besar membutuhkan perencanaan yang baik sesuai tujuan, GF memiliki perencanaan dan kesinambungan tim dimulai dari program hingga dikomunikasikannya sebuah program. Komunikasi menggunakan sebuah platform Instagram salah satunya. Dalam jangka waktu tertentu setiap program yang dikampanyekan dapat di publikasikan di media Instagram.

Dalam percepatan teknologi kini, selain melalui media massa, penting juga penggunaan media sosial dalam berkomunikasi sebuah individua, organisasi atau perusahaan. Kehadiran New Media yang melahirkan melahirkan media sosial menjadi benefit tersendiri di dunia jejaring internet yang luas. Bahkan kini penggunaan smartphone yang terhubung dengan internet tidak bisa lagi di elak di kehidupan sehari-hari. Instagaram juga dimanfaatkan oleh GF untuk mempublikasikan program-program, hingga pada tahap pengadaan program di Instagram sendiri.

Dalam media sosial pemilik akun atau @greenerationid dapat berinteraksi langsung dengan audience, dengan fiturnya yang dapat publik atau private. Media sosial memiliki fiturfitur tersendiri yang memudahkan untuk berinteraksi, peran media pula dapat menjadi alat suatu kampanye.

Menurut Dijk (2003) dalam (Nasrulla 2016:11) Media sosial adalah platform media yang memfokuskan pada eksistensi pengguna yang memfasilitasi mereka dalam beraktifitas maupun berkolaburasi, Karena itu media sosial dapat dilihat sebagai medium( fasilitator) online yang menguatkan hubungan antar pengguna sekaligus sebagai sebuah ikatan sosial.

@ greenerationid memfasilitasi kampanye GF dan juga dapat dijadikan sebagai wadah berkolaborasi dengan public lain. Sebagai sebuah wadah tentunya hal ini memudahkan dan mempertemukan public-publik yang memiliki kesamaan tujuan. Hubungan itu pun yang memperkuat sebuah ikatan di media sosial pun keadaan nyatanya. GF banyak berkolaborasi di program yang dilakukannya, seperti \#citarumrepair atau \#indonesiaLawanCorona. Instagram dirasa menjadi media yang dapat mengkomunkasikan program GF. "Menurut Schrage, kolaborasi merupakan upaya penyatuan berbagai pihak untuk mencapai tujuan yang sama dalam Harley dan Bisman, (2010: 18)". GF dapat menyatukan pihak-pihak yang memiliki tujuan yang sama, dan dipercaya untuk melakukan program-programnya. Hal ini juga berbanding lurus dengan hitungan secara kualitatif di Instagram nya. Melihat followers dan engagement.

Lingkup Instagram dalam mendukung program yang dilakukan Greeneration Foundation GF memiliki Karakteristik konten yang mendidik, membujuk, mengisahkan sebuah cerita, berbagi, temuan.

Dalam lingkupnya GF berfokus pada program yang akan disebarluaskan kepada masyarakat, sebagai NGO juga GF bermitra atau berkerjasama untuk mewujudkan sebuah program.

Tentunya perlu komuikasi, Instagram berada pada lingkup komunikasi di dalam GF. Terdapat Communication and Promotion dan salah satunya terdapat tim media yang mengelola Instagram.

1. Instagram berperan sebagai penghubung GF terhadap masyarakat (public) dengan kampanye yang dilakukan.

2. Instagram sebagai medium yang menampilkan image/ citra

3. Instagram berperan sebagai salah satu penghubung/ leads GF terhadap publik atau pihak yang ingin melakukan kampanye Bersama dengan GF.

4. Instagram/ social media menjadi salah satu publikasi parameter capaian sebuah program. Instagram GF memenuhi karakteristik dari fungsi media sosial, dalam media sosial terdapat tiga hal; Sharing, Collaborating, Connecting(Puntoadi, 2011).

Terdapat aktivitas dan peranan yang dapat dilakukan di media sosial. Dalam dunia ke 
PR-an dimana PR sebagai jembatan antara public dengan public lainnya. DEngan adanya PR disuatu perusahaan dapat membantu agar masyarakat atau public tersambung dengan baik tanpa adanya kesalahpahaman antara satu sama lain. Sebagaimana Menurut Cutlip, Center dan Broom, Public Relations adalah fungsi manajemen.

Dalam (Yulianita, 2012:35-36) Public Relations adalah fungsi manajemen yang menilai sikap publik, mengedintifikasi kebijaksanaan dan tata cara organisasi demi kepentingan publiknya, serta merencanakan suatu program kegiatan dan komunikasi untuk memperoleh pengertian dan dukungan publiknya

Dari GF menilai sikap publiknya dengan riset yang dilakukannya serta mengidentifikasinya yang langsung di aplikasikannya kedalam sebuah visinya. Tentunya pergerakan yang dilakukan GF berorientasi kepada kepentingan publiknya. GF merencanakan suatu kegiatan dan mengkomunikasikannya untuk mendapatkan awareness dari audience nya dan untuk mendapatkan dukungan dari public yang ditargetkan.

Sehinga peneliti melihat adanya fungsi manajemen yang dilakukan GF serupa dengan pengertian PR . Peneliti berfokus pada lingkup komunikasi kepada public untuk mendapatkan pengertian dan dukungan. Peneliti melihat adanya peranan PR dalam menjalankan aktivitasnya, utamanya di pengelolaan komunikasi tim media, seperti menurut Ruslan (2014:15) adanya Communicator, Relationship, Back Up Management, Good Image Maker.

Dalam website nya Communication and Partnership, membawahi tim Fundraising, R\&D dan media. Pengelolaan Media yang dielaborasi kedalam 7 media salah satunya Instagram. Disini setelah ditentukannya program dalam kampanye sesuai yang ditentukan, tim media bergerak dalam mengkomunikasikannya.

Instagram kini menjadi jembatan antara penguna, disini@greenerationid dengan audience atau followersnya. Sebagai seorang PR perlu menjalankan komunikasi yang baik maka dari itu perencanaan yang baik dan juga menjadi komunikator bagi organisasi atau spokenperson. Lalu PR juga sebagai jembatan antara pihak internal dan eksternal yang menciptakan atau menimbulkan suatu pengertian yang saling diantara kedua belah pihak, Instagram disini pun hadir untuk menjembatani, antara pihak internal dan eksternal. Lalu dalam peran PR dimana sebagai jembatan apabilan PR dapat menjalankan aktivitasnya dengan baik maka peran PR dapat mengatasnamakan perusahaan nya dengan baik pula. @ greenerationid memiliki followers yang tiap bulan atau tahunnya bertambah, peningkatan jumlah mitra juga di akui Vanessa berimplikasi dari hadirnya Instagram mereka. Yang terakhir sebagai Good Image Maker, susuai tujuan PR yaitu citra, maka seorang PR dalam kegiatan nya harus dapat membuahkan citra yang baik bagi perusahaan atau organisasinya. Terlepas dari GF yang telah dikenal dari programnya sebelum Instagram hadir, tetapi Instagram GF telah melakukan perencanaan yang memang ditujukan untuk menciptakan citra yang baik.

Dengan pelbagai fitur yang ada dalam Instagram yang dimanfaatkan oleh GF. Kampanye yang dilakukan dapat terkomunikasi sesuai gaya yang dimiliki oleh GF sendiri. Hal ini juga berkaitan dengan Reputasi yang memang sengaja diciptakan oleh GF. Reputasi ini berimplikasi terhadap citra yang beredar di masyarakat kepada GF, padangan eksternal ini pun kini dapat dilihat dengan mudah melalui Instagram. Selain melalui media mass akita tahu akan program yang dilakukan GF yang menghasilkan opini public, GF juga mempublikasikan melalui media-media yang dimiliki GF salah satunya Instagram. Brand image GF atau citra/ image organisasi seperti menurut Frank Jefkins didasarkan pada.

1. Reputasi (baik buruknya nama perusahaan),

2. Aktivitas (kegiatan-kegiatan nya),

3. Perilaku manajemen perusahaan. (Yulianita, 2021:44)

Kampanye yang dilakukan juga mendapatkan respon positif menurut Vanessa dan temuan peneliti, baik itu dengan followers atau public yang bekerjasama dengan GF. Kenaikan followers menjadi salah satu indicator adanya kepercayaan public, lalu engagement dan konten yang konsisten dari GF bisa memunculkan kepercayaan public terhadap program-program yang dilakukan. 
1) Public Understanding (adanya kepercayaan publik terhadap organisasi), 2) Public Confidence (adanya kepercayaan publik terhadap organisasi), 3) Public Support (adanya unsur dukungan dari publik terhadap organisasi), dan 4) Public Cooperation (adanya kerjasama dari publik terhadap organisasi). (Yulianita, 2012: 50)

GF memiliki kesepahaman mengenai isu yang diangkatnya terhadap publiknya, GF juga memiliki kepercayaan terhadap publiknya melalui konten yang dipublikasikan atau program yang dilakukan. Public Support seperti yang dikemukakan vanessa kini, GF tiap tahunnya memegang program yang bisa dibilang "naik kelas" sehingga timbul kepercayaan pada GF untuk melakukan program-program yang dilakukan bersama mitranya.

\section{Proses tim media dalam mengelola akun Instagram @greenerationid sebagai media kampanye ramah lingkungan}

Dalam pengelolaannya, tim media bertanggungjawab terhadap media yang digunakan GF.Terdapat proses yang telah di atur. Tim Media beranggotakan 5 orang. Tahapan yang dilakukan,

1. Penentuan pilar konten

2. Editorial Plan selama satu bulan

3. content brief perminggu

4. pembuatan konten

5. post dan maintaining

Pengelolaan konten ini juga telah diatur dengan Batasan yang diramu kedalam guideline hingga dapat terciptanya brand design. Selain itu, pada lingkupnya Instagram berada di komunikasi, tetapi proses tim media juga dibantu oleh divisi lainnya dan nantinya akan terjadi sinkronisasi pula terhadap lingkup program.

Penggunaan fitur digunakan oleh GF dalam Instagramnya untuk menarik audience dan menambah followers baru dalam interaksinya. Brief konten yang mendadak menjadi hambatan bagi desainer

Pengelolaan dibutuhkan agar dapat sampai kepada tujuan, adanya tahapan-tahapan perlunya perencanaan dalam sebuah kegiatan. Proses perencanaan inilah yang merupakan sebuah bagian yang menjadi perjalanan bagi aktivitas tersebut. Pastinya akan berbeda perencanaan setiap perusahaan atau organisasi, bergantung pada tujuan atau visi yang ingin di capai. GF dalam capaian ingin menjadi wadah yang dapat mengakomodasi dalam isu lingkungan bagi perusahaan atau organisasi lainnya. Untuk mencapai itu, perlunya komunikasi yang luas, masyarakat atau public-publik perlu mengetahui apa yang dilakukan GF. Sehingga digunakannya Instagram tidak serta merta hanya digunakan asal posting saja. Dalam dunia ke PR-an terdapat empat tahap operasional PR yang dikemukakan oleh (Cutlip \& Center dalam Yulianita, 2012: 123) bahwa operasional Public Relations haruslah melalui 4 tahapan yaitu: 1) Defining Public Relations Problems, 2) Planning and Programming, 3) Communicating 4) Evaluation.

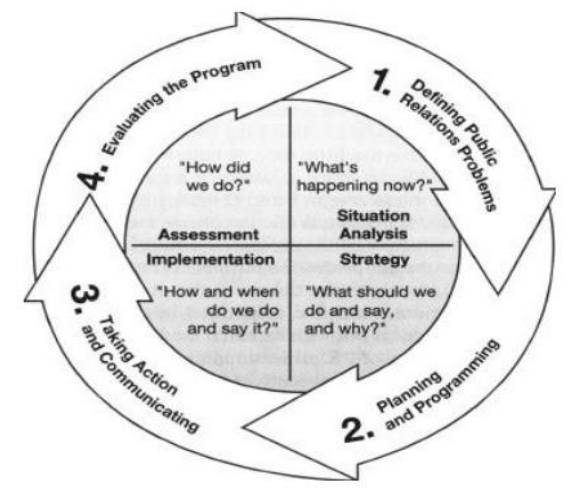

Gambar 1. Proses Operasional PR (Sumber: Yulianita, 2012:129)

Dimana empat tahapan tersebut memiliki satu kesatuan yang saling menghubungkan 
satu sama lain, proses ini pun banyak dilakukan oleh humas atau PRO. Tahapan ini dilalui oleh GF khusunya tim media yang dibantu oleh tim internal lainnya. Setiap pelaksanaan program yang ingin dipublikasikan, tahap operasional PR ini dilakukan dan saling berkesinambungan hingga kini.

1. Fact- Finding, dalam tahapan ini tim media melakukan riset, dan riset ini pula dilakukan oleh tim GF secara keseluruhan karena program telah ada. Tetapi dalam hal publikasinya, tim media dibantu pula oleh tim lainnya untuk menghasilkan sebuah konten-konten. Mengkaitkan dengan isu yang hangat dibicarakan dimasyarakat. Bersama tim R\&D yang memberikan insight nya hal ini menjadi lebih baik. Tim media mengolah mana konten yang dapat dipublikasikan dan menarik. Fact Finding ini terus dilakukan setiap bulannya, bahkan memungkinkan terjadi dalam hariannya.

2. Planning and Programming, tahapan ini berbicara mengenai kemasan dari informasi yang akan di publikasikan menjadi konten yang di upload di platform media sosial GF, salah satunya Instagram. Tim media telah memiliki brand guideline yang bisa memudahkan, guideline ini bisa berubah seperti yang dilakukan mereka pada 2019 awal. Penentuan cara berkomunikasi dan brand voice, do's or don't dalam pengunggahan konten (segala fitur yang diberikan Instagram termasuk caption) atau berinteraksi dengan audience. Pembentukan content pillar dan editorial termasuk kedalam planning dan programming, dimana tim media menentukan dan mengatur konten mana saja yang akan diciptakan dalam jangka waktu yang ditentukan, satu tahun atau periode yang ditentukan dalam content pillar, editorial plan yang di buat perbulan atau perminggu, dan konten brief yang dapat dilanjut ke tahap berikutnya.

3. Taking Action and Communicating, melanjutkan dari tahapan yang telah dilakukan menghasilkan bahan yang akan diciptakan. Berkat riset, tim media mengetahui konten yang akan diciptakan, lalu berkat planning dan programming melalui editorial plan menghasilkan konten brief perpostingannya. Hal ini sejalan dengan operasional PR dimana perlakuan yang telah diatur dapat dilakukan dan dikomunikasikan (maintanace), Seperti menurut Ratih dimana kini Instagram GF terasa seperti dimanusiakan "Kalau sekarang aku lihat sekarang dibuat seakan-akan kayak orang aja gitu (Ratih)"

4. Evaluating, dalam tahap ini tentunya mengukur apa yang telah dilakukan. Banyak cara dalam proses ini. Dapat dilakukan secara kualitatif atau pun kuantitatif. Variabel yang dihadirkan pun dapat disesuaikan dengan apa yang ingin dituju. Dalam hal ini GF mengunakan Objective Key Result (OKR), menurut The OKR guide: From Strategy to execution.

The OKR Framework is a Tool that Will Ensure a Unified Cadence of Progress in Your Company and Build the Gap Between Strategy and Executive on among Your Workforce in a Year Without Having the Need to Constantly"BossEveryone Around" (Kerangka OKR adalah alat yang akan memastikan irama kemajuan yang terpadu di perusahaan anda dan membangun kesenjangan antara strategi dan eksekusi di antara tenaga kerja anda dalam setahun tanpa perlu terus-menerus "bos adalah semua orang di sekitar"

Maka jika ada sesuatu yang sangat berbeda tentang OKR, itu menjadi fakta bahwa OKR merupakan alat penentu tujuan dan kerangka kerja manajemen yang secara efisien menyinkronkan setiap orang dalam sebuah organisasi untuk secara strategis bergerak menuju tujuan jangka pendek dan jangka panjangnya. Lalu Adapun evaluasi yang dilihat dari pergerakan platform itu sendiri, Instagram memiliki fitur yang dapat penggunanya lihat performa dari akun yang dikelola. Evaluasi yang telah dilakukan terlihat dari GF seperti rebranding mereka dari persampahan ke SCP, guideline dan cara berkomukasi.

Konten yang diciptakan juga sejalan dengan kampanye yang dilakukan, sesuai dengan tujuan dari PR sendiri. Dalam Kampanye PR, walaupun PRO tidak ada tetapi fungsi manajemen yang menciptakan kepercayaan goodwill, dan kejujuran dalam menyampaikan pesan atau informasi juga publikasi yang positif kepada audience nya dilakukan GF dengan dukungan perencanaan serta Teknik dalam berkampanye untuk memperoleh citra.

Tim media menyampaikan pesan kampanye GF melalui platform yang digunakan untuk menumbuhkan penafsiran yang menyenangkan dan informatif. Dalam proses kampanye yang 
dilaksanakan, seorang PRO juga perlu terkoordinasi, hal ini juga dilakukan oleh tim media yang terkoordinasi dengan tim lainnya dalam riset. Seperti yang Vanessa kemukakan, tim media pernah mengalami masa hilang arah, dengan adanya evaluasi kini tim media dapat terkoordinasi, memiliki perancangan komunikasi program yang dapat mencapai tujuan yang telah disepakati Bersama. Dengan penyelarasan dengan target audience yang ada dengan brand desain yang diciptakan GF berhasil memperhatikan ekistensi dalam menciptakan nilai-nilai kepercayaan terhadap publiknya dalam melakukan kampanye. Dengan program yang dilakukan dan publikasi yang terencana, GF juga memiliki jati diri (brand identity) citra (brand image) yang dapat diterima oleh publiknya. Dalam postingan pesan GF yang terkandung nilai-nilai dalam isu lingkungan di terima publiknya.

Proses ini lah yang menjadi GF dapat diketahui oleh publiknya. Identitas yang dikenal melalui logo, konten, website identitas brand berupa fisik atau non-fisik lainnya. Gaya komunikasipun memperlihatkan reputasi GF yang mendapat respon dari followers nya. Walaupun terdapat hambatan-hambatan yang terjadi, GF tetap mendapat reputasi dan citra yang telah dibentuk. Kini, GF terus melakukan perbaikan dalam kampanye program-programnya.

\section{Kesimpulan}

Berdasarkan hasil penelitian mengenai "Peran Instagram @greenerationid Sebagai Media Kampanye Ramah Lingkungan "dengan studi kasus kampanye Non-Government Organization Greeneration Foundation Bandung" yang telah dipaparkan pada bab sebelumnya, maka dapat disimpulkan.

1. Melalui program-program yang dilakukan Greeneration Foundation yang mengkampanyekan isu SDG's poin ke-12 yaitu Suistainable Production and Consumtion, Gembutuhkan khalayak yang besar dan membutuhkan mitra Kerjasama dalam menyukseskan program yang diciptakan. Sebagai NGO non profit di bidang lingkungan dan memiliki visi untuk mengakomodasi kolaborasi antar pemangku kepentingan untuk mendorong konsumsi dan produksi yang berkelanjutan, GF membutuhkan komunikasi yang terencana dengan baik. Pemilihan platform menjadi alat untuk mengkomunikasikan program GF agar dipahami dan dipercaya oleh publiknya, salah satunya Instagram,

2. Terdapat dua lingkup yang peneliti bagi dalam aktivitas kampanye, antara program dan komunikasi. Instagram berada pada lingkup komunikasi dimana penggunaan media sosial GF berfungsi sebagai Sharing, Collaborating, Connecting. Dalam penggunaanya pun terdapat peranan PR sebagai fungsi manjemen, terdapat aktivitas Communicator, Relations Back Up Management dan Good Image Maker yang dilakukan tim media. Dimana hal tersebut untuk memperoleh citra yang positif atau kepercayaan publiknya,

3. Melalui konten yang diolah dan dikelola oleh tim media, melalui proses pembuatan content pilar, editorial plan, menentukan tema, konten brief hingga ke dalam bentuk visual maupun audiovisual. Pengelolaan ini pun di optimasikan melalui fitur-fitur apa saja yang disediakan oleh Facebook atau Instagram. Aktivitas ini juga memenuhi tahapan proses operasional PR.

\section{Acknowledge}

Peneliti ingin mengucapkan terimakasih kepada Vanessa Letizia selaku Executive Director Esa Khairina Husen selaku Media Manager Faqih Maulana selaku Graphic Designer \& Videografer. Terimakasih kepada dosen pembimbing peneliti Prof. Hj. Neni Yulianita, Dra,. M.S serta kepada seluruh Dosen Fakultas Ilmu Komunikasi Universitas Islam Bandung.

Terima kasih kepada pihak-pihak yang telah disebutkan sehingga penelitian dengan judul "Peran Instagram @ Greenerationid sebagai Media Kampanye Ramah Lingkungan" dapat terwujud. 


\section{Daftar Pustaka}

[1] Cresswell, John W. Research Design: Pendekatan Metode kualitatif, Kuantitatif dan Campuran. Yogyakarta: Pustaka Pelajar

[2] Gunawan, Imam. 2015. Metode Penelitian KualitatifTeori dan Praktik. Jakarta: PT. Bumi Aksara.

[3] Mulyana, Deddy. 2012. Ilmu Komunikasi Suatu Pengantar. Bandung: PT Remaja Rosda Karya.

[4] Nasrullah, Rulli. 2016. Media Sosial: Perspektif Komunikasi, Budaya dan Sosioteknologi. Bandung: Simbiosa Rekatama.

[5] Puntoadi, Danis. 2011. Menciptakan Penjualan Melalui Social Media. Jakarta: Elex Media Komputindo.

[6] Riduwan. 2004. Metode Riset. Jakarta: Rineka Cipta.

[7] Ruslan, Rosady. 2013. Kiat dan strategi kampanye public relations. Jakarta: PT. Rajagrafindo Persada.

[8] Satori, Djam'an dan Aan Komariah. 2010. Metodologi Penelitian Kualitatif. Bandung : Alfabeta

[9] Sugiyono. 2017. Metode Penelitian Kuantitatif, Kualitatif dan R\&D. Bandung: Alfabeta.

[10] UNEP. 2015. Sustainable Consumption and Production Global edition A Handbook for Policymakers. Kenya: ISBN: 978-92-807-3364-8

[11] Yin, Robert K. 2019. Studi Kasus: Desain \& Metode. Depok: PT. Rajagrafindo Persada.

[12] Yulianita, Neni. 2012. Dasar-Dasar Public Relations. Penerit: LPPM UNISBA, Bandung.

[13] Neni. M.E. Fuady. (2015). Pendapat Pimpinan Universitas Swasta Tentang Manfaat Media Sosial Bagi Kinerja Profesi Public Relations. ISSN: 2477-1376 Hal 27

[14] https://www.Instagram.com/

[15] http://sdgs.bappenas.go.id/dashboard/\#!/pages/landingPage.html

[16] https://www.greeneration.org/green-info/sampah-plastik-di-lautan/

[17] https://ppkl.menlhk.go.id/website/reduksiplastik/pengantar.php

[18] https://www.greeneration.org/green-info/sampah-plastik-di-lautan/

[19] https://peraturan.bpk.go.id/Home/Details/73225/perpres-no-97-tahun-2017 